\title{
Efficacy of eastern Australian rainforests and topography as fire refugia under anthropogenic climate change
}

Myles Jay Bennell ( $\square$ m.bennell@uqconnect.edu.au )

The University of Queensland https://orcid.org/0000-0001-5333-3499

Philip Le C. Stewart

UQ: The University of Queensland

Patrick T. Moss

UQ: The University of Queensland

\section{Research Article}

Keywords: black summer, bushfire, climate change, critical transitions, eastern Australia, fire refugia, rainforest, sub-tropical, tipping points, topographic refugia

Posted Date: March 31st, 2021

DOI: https://doi.org/10.21203/rs.3.rs-295560/v1

License: @ (1) This work is licensed under a Creative Commons Attribution 4.0 International License. Read Full License 


\section{Abstract}

Background: The 2019-20 Australian bushfire season was the most environmentally detrimental bushfire season on record. The extreme heat and drought exposed normally fire-resistant communities to uncharacteristically dry fuel loads and abnormally high severity burning. In eastern Australia this included mesic rainforest environments (including the World Heritage listed Gondwana Rainforests of Australia), which are often highly sensitive to fire, contain high biodiversity values, are critical habitat for threatened species, embody distinct endemism, provide valuable ecosystem services and are critical for terrestrial carbon storage. East coast rainforests are also highly fragmented, with less than half of pre-European levels remaining. Increases in fire frequency and intensity associated with climate change may threaten these already fragmented rainforest environments. This study considers the efficacy of rainforest refugia under a heightened bushfire climate, via spatial analysis of burn extent, burn severity and topographic characteristics for rainforests during the 2019-20 bushfire season within the Eastern Australian Temperate and Subtropical Forests Conservation Management Zone.

Results: Burn severity, vegetation and elevation datasets were merged and analysed across mid-eastern Australia. A significant portion of rainforest was fire affected across the study area $(\sim 17 \%)$, with $\sim 5 \%$ burnt to a high or very high severity. Elevation, topographic position (i.e. valleys), slope and aspect all contributed to maintaining rainforest fire refugia. The study resulted in a mapping product that can be utilised by researchers and protected area managers to locate and assess burnt rainforest in mid-eastern Australia.

Conclusions: This study enables the identification of rainforest fire refugia and threatened rainforest communities for future research and conservation efforts in eastern Australia. The results also demonstrate the potential of climate change to enact widespread rainforest declines, with potentially dire consequences for biodiversity and ecosystem services. This event and recurrent fire events may enact positive climate feedback systems by enabling pyrophytic vegetation expansion and converting rainforest carbon pools into a carbon source.

\section{Background}

Anthropogenic climate change is altering bushfire regime's in Australia, with increases in surface temperature, extreme heat events, dry lightning ignitions and drought contributing to enhanced bushfire intensity and frequency in many regions (BOM and CSIRO 2020; Bowman et al. 2020). This shift was evident during the severe 2019-20 Australian 'Black Summer' bushfire season, which burned almost 19 million ha in southern and eastern Australia with significant consequences for human health, the economy and the environment (Oldenborgh et al. 2020; Filkov et al. 2020). Environmental consequences included reports of extensive burning in fire-sensitive rainforests across the east coast, including an estimated $50 \%$ of world heritage protected Gondwana Rainforests of Australia (Nolan et al. 2020). This event was predominantly a result of extreme heat and prolonged drought; which can be attributable in part to anthropogenic climate change (van Oldenborgh et al. 2020; BOM 2019; Sanderson and Fisher 2020; Phillips and Nogrady 2020). Whilst these fire weather conditions were an anomaly, forecasts suggest that climatic conditions leading to this 'unprecedented' season may be average by 2040 and well below average by 2060 if our present emissions trajectory is maintained (Sanderson and Fisher 2020).

\section{Rainforest-fire antagonism}

Rainforest distribution, fire behaviour and climate have been interlinked over the past millennia in eastern Australia (Cary et al. 2012; Stewart and Moss 2015). Charcoal and pollen analysis reveals a trend of increased rainforest taxa and reduced charcoal abundance during cooler, wetter and less fire prone climates, particularly during the mid-Holocene (around 7,000 to 3,500 years ago) (Dodson et al. 1986, Donders et al. 2007; Moss et al. 2013). Conversely, during periods of increased aridity, such as the late Holocene (last 3,500 years) and linked to intensification of the El Niño Southern Oscillation phenomenon (particularly the dry El Niño phase), pyrophytic taxa in across eastern Australia appear to have expanded and rainforest taxa declined, corresponding with increases in charcoal abundance (Stewart 2017; Donders et al. 2007; Donders et al. 2008). Spatial variability in rainforest taxa is also evident, with heterogenous shifts in rainforest distribution within regional landscapes, indicating that areas of refugia may enable rainforest persistence during less favourable climates (Moss et al. 2013).

Rainforest typically occupies areas of the landscape in which conditions are not conductive to fire (Wood et. al 2011), preferring locations that: are high in rainfall and mesic in nature (such as the tropics, high elevations and coastal areas); contain fire retardant skeletal substrates (such as rocky outcrops); and are in topographic locations which are protected from heat, wind and upward fire spread (such as valleys) (Wood et al. 2011; Holz et al. 2020; Ash 1988; Williams et al. 2012). 
Rainforest systems and species have a range of internal mechanisms to reduce the occurrence and severity of bushfire. A closed canopy reduces the amount of available light for the understory, restricting ground cover such as grasses, distributing biomass away from the understory and ultimately reducing fuel loads (Hoffmann et al. 2009; Cochrane 2003; Williams et al. 2012). A closed canopy also produces a micro-climate within the rainforest that is divergent from the local and regional climate, diminished bushfire weather by reducing wind speed, lowering temperature and increasing relative humidity (Cochrane 2003; Hoffmann et al. 2009; Murphy and Bowman 2012; Staver et al. 2011). As a result, bushfire in most rainforests is relatively infrequent, and when fire does occur, the mesic microclimate and reduced fuel availability typically ensures that vegetation burns to a low severity (Williams et al. 2012). Despite the generally low severity of rainforest fire, many rainforest systems are sensitive to fire and recovery can be slow (Hjerpe et al. 2001; Cochrane and Schulze 1999).

It should be noted that the pyrophobic fire sensitive narrative for rainforest environments is not universally applicable, with the diverse range of rainforests responding divergently to fire. For example, some tropical rainforest species have the ability to regenerate after low and moderately severe fire (Williams 2000), likewise, whilst thin bark and stems generally make rainforest species more vulnerable to fire, some rainforest species have adapted to resprout post-fire (Hoffmann and Solbrig 2003; Bowman 1991). Even though many rainforest species can withstand fire events, cumulative frequent burning often still results in degradation (Williams, et al. 2012; Bowman 2005; Fensham et al. 2006).

Under extreme climatic or weather conditions, such as prolonged drought and extreme heat, rainforest resistance to fire is reduced as fuel dryness and combustibility increases, leaving rainforest at higher risk of burning (Collins et al. 2019). As many rainforest species have not adapted to tolerate intense or frequent burning, they are particularly vulnerable, with potential for direct tree mortalities, reduced species richness and reduced canopy cover (Cochrane and Schulze 1999). The reduction in canopy cover diminishes the mesic qualities of the pre-fire system and results in a system more vulnerable to further burning and pioneer invasion (Cochrane and Schulze 1999). Critically, if fire returns to recently burnt rainforest, then recovery can be hindered, with the potential to result in a shift to a new ecosystem (Mark et al. 2001; Lindenmayer et al. 2011; Murphy and Bowman 2012). As a result, fire frequency and severity are key controls over rainforest distribution (Bowman 2000).

With frequent and intense burning non-rainforest species normally excluded by the shaded and mesic nature of the closed canopy can take advantage of a post-fire opening, often assisted by faster growth and swifter post-fire reproductive capacity (Murphy and Bowman 2012). Once embedded, pyrogenic pioneer species can encourage and enhance further fire by shifting fuel structure and composition: triggering a positive fire feedback system in favour of pyrogenic over pyrophobic vegetation (Staver et al. 2011; Murphy and Bowman 2012). Consequently, rainforest that is not surrounded by pyrogenic vegetation may be more likely to recover, even after severe bushfire (Fletcher et al. 2014).

In the Bunya mountains of eastern Australia, Indigenous Australians likely took advantage of this rainforest vulnerability for hunting and agricultural purposes, utilising fire to maintain grassland at the expense of dry rainforest (Fensham et al. 2006; Foreman 2016; Moravek et al. 2012; Webb 1964). Fensham et al. (2006) found that frequent burning can withhold rainforest boundaries, however, even biennial burning did not prevent eucalypt colonisation of grassy balds in the Bunya mountains. This demonstrates the potential for high frequency fire regimes to limit rainforest distribution and highlights the invasion potential of eucalypt forests under high fire return intervals.

In the long-term absence of fire, pyrophobic species can encroach on fire-dependent systems (Baker and Catterall 2015; Murphy and Bowman 2012; Baker, et al. 2020). Butler et al. (2014) found that there has been an expansion of rainforest in areas of subtropical Eastern Australia between 1961 and 2006, likely as a result of a reduction in the traditional burning practices. Fensham and Fairfax (1996) found that between 1951 and 1991 rainforest (and eucalypt forest) has been able to reinvade grassy balds in the Bunya mountains, again linked to the cessation of traditional fire management, which may have kept encroaching rainforest at bay (Fensham et al. 2006). Also evident in fire suppressed coastal regions of eastern Australia, rainforest pioneer species are invading long unburnt open forests, providing shading that suppresses understory growth in favour of mesic species, reducing the vegetation flammability and enabling a shift from a fire-dependent ecosystem towards a fire-resistant ecosystem (Bakeret al. 2020). Upon invasion, rainforest species can reduce plant diversity and density in open forests, diminish critical habitat and drive localised species extinctions (Baker and Catterall 2015; Baker et al. 2020a; Baker et al. 2020b).

\section{Surpassing critical thresholds}

Page $3 / 20$ 
Perhaps one of the greatest threats that increased bushfire activity poses to rainforest distribution, is the danger of enacting a critical transition, a process in which a system surpasses a critical threshold or 'tipping point' in which a sharp shift to a new state is unavoidable (Scheffer et al. 2012). Critical thresholds are a major concern with the rapidity of present climate change and have been identified in many ecological, hydrological and geological systems, from glacial retreat (Rosier et al. 2020) to coral reef decline (Bellwood et al. 2004).

Heightened bushfire activity creates a risk of exceeding the resilience of pyrophobic vegetation, in which a transition to an alternate vegetation state is enacted (Staver et al. 2011; Murphy and Bowman 2012). Hoffmann et al. (2012) defines two key fire-vegetation thresholds which control shifts to alternative stable states where resources enable:

- the fire resistance threshold in which pioneer species become a sufficient size to withstand returning fire, and

- the fire suppression threshold, in which canopy cover becomes sufficient to suppress fire weather and surface fuel loads.

Concern is mounting that global, climatically driven increases in drought and stand-replacing fire will lead to a skew of this balance and a conversion of forest systems to non-forest systems (Seidl et al. 2016; Millar and Stephenson 2015). The premise for this study, is the concern that more frequent and more intense fire within rainforests may initiate a positive feedback cycle on a continental scale that causes more severe and more frequent burning, leading to eventual collapse of some fire sensitive communities in eastern Australia (Fletcher and Thomas 2010; Fletcher et al. 2018).

Vitally, tipping points are not always observable or predictable, with potential for seemingly healthy systems to be in the process of a 'domino effect' in which collapse is inevitable (Scheffer et al. 2012). Conversely, modelling inaccuracies can raise a false alarm for collapse in actually healthy systems (Wagner and Eisenman 2015).

Concerningly, tipping points rainforests may be exacerbated or instigated by compound stressors such as invasive species, logging, pathogens and inappropriate fire management (Fonseca et al. 2019; Tepley et al. 2016; Cochrane and Schulze 1999). This is especially concerning in eastern Australia, where just half of pre-1750 rainforest vegetation remains, and what remains is highly fragmented (DEE 2015). Likewise, drought is also a key driver of bushfire, is particularly threatening to rainforests and may reduce post-fire regeneration capacity (Millar and Stephenson 2015; Harvey et al. 2016; Littlefield 2019).

\section{Fire Refugia}

The concept of refugia has been put forward as an essential component of biodiversity persistence during climatic changes, defined as 'habitats that components of biodiversity retreat to, persist in and can potentially expand from under changing environmental conditions' (Keppel et al. 2012, p. 393). The refugia concept has been readily applied to disturbance events such as bushfires, with the term fire refugia referring to unburnt or less severely burnt areas within a bushfire burn extent (Krawchuk et al. 2016; Meddens et al. 2018). Fire refugia can provide shelter during fire events, maintain soil stability, provide resources immediately after fire events, enable longer term population recovery and support retention of ecosystem function (Meddens et al. 2018).

Research has identified topography as a key contributor to fire refugia (Wood et al. 2011; Holz et al. 2020; Krawchuk et al. 2016; Collins et al. 2019; Couper and Hoskin 2008; Cadd et al. 2019). Topography provides sheltered mesic microclimates, antagonistic to the exposed, drier climates favourable to fire spread (Wood et al 2011; Holz et al. 2020). These areas include sheltered valleys, rocky outcrops with skeletal substrates, steep poleward facing slopes and higher elevations, whereas fire prone landscapes include ridges, lower elevations, flat areas and non-poleward facing aspects (Wood et al. 2011; Holz et al. 2020; Williams et al. 2012; Dodson and Root 2013). Not only does topography enable refugia by shielding species and communities during fire, it also provides climatic conditions important for postfire recovery (Littlefield 2019; Harvey et al. 2016).

Rainforests can persist in the fire protected mesic environments provided by montane topography (Holz et al. 2020; Wood et al. 2011). Some east coast montane areas, such as north east NSW, are identified as distinct areas of endemism, suggesting that they may be important refugia for rainforest species (Reside et al. 2013; Weber et al. 2014).

In south eastern Australia studies have found that extremities of drought and fire weather can weaken the mesic qualities of topographic fire refugia (Collins et al. 2019), potentially explaining why rainforests were vulnerable to the drought fuelled burning of the $2019-20$ season. Furthermore, extremities in drought may also reduce post-fire recovery dynamics (Harvey et al. 2016; Tepley et al. 2017; Littlefield 2019). Little is yet known as to how severely rainforest vegetation on the east coast was affected by the drought-fuelled $2019-20$ season

Page $4 / 20$ 
(Nolan et al. 2020), with even less clarity as to the effectiveness of topographic refugia. Clarifying the impact of this event on rainforests may be critical for determining the extent and effectiveness of refugia for rainforest persistence as climate change progresses.

\section{Study Aims}

The aims of this study are to examine the extent and severity of the 2019-20 bushfire season on rainforest vegetation within the Eastern Australian Temperate and Sub-tropical Forests Conservation Zone (EATSF). This study also aims to identify the topographic characteristics of persistent rainforest fire refugia within the region, to aid conservation of important rainforest refugia as well as rainforests most vulnerable to future climatic shifts. We theorise that the extent of burnt rainforest within the conservation zone is significant and that topographic variables such as slope, aspect, elevation and topographic position index were critical for reducing the severity and extent of burnt rainforest. The null hypothesis is that burn extent was not significant and that the mean burn severity for topographic variables remains constant across burn severity categories. The location of this study is important, as research into the rainforests-bushfire interactions primarily focuses in either the temperate south-east or the topical north-east. As far as the author is aware, no study of rainforest fire refugia has been undertaken on such a broad scale on the east coast or elsewhere globally.

\section{Study Area}

Australia is divided into 23 Conservation Management Zones, characterized by their ecological and threat characteristics and aligned with the Interim Biogeographic Regionalisation of Australia (DEE 2015). The benefit of conservation zones is that they enable long term conservation planning and natural resource management that transcends traditional governance boundaries such as state borders (DEE 2015). This is particularly important for measuring bushfire risk and impact, with severity assessment often limited to the governance boundaries of which bushfires are not restricted.

This study focuses on the Eastern Australian Temperate and Subtropical Forests Conservation Management Zone (EATSF; Figure 1). The zone encompasses approximately 16 million hectares on the east coast of Australia, with a high human population density of 34.82 people per square kilometre (DEE 2015). The National Reserve System comprises of $19 \%$ of the zone, with $45 \%$ of all native vegetation cleared since pre-European levels (DEE 2015). Just 1.2\% of the zone is recognised under native title (DEE 2015).

The EATSF is composed primarily of Eucalyptus communities, which are heavily degraded since pre-1750 levels (DEE 2015 ). Eucalyptus woodlands with a tussock grass understory encompassed $\sim 38.2 \%$ of vegetation pre-1750, now representing just $7.5 \%$ (DEE 2015 ). Likewise, approximately half of pre-1750 rainforest vegetation no longer exists, and what does remain is often highly fragmented due to a range of anthropogenic pressures (DEE 2015). Sub-tropical rainforest now makes up approximately $2.7 \%$ and warm temperate rainforest makes up approximately $1 \%$ of the zone (DEE 2015). The current distribution of the rainforest major vegetation group within the EATSF is described in Figure 2.

EASTF rainforest vegetation is disjunct in distribution and restricted to areas with high annual rainfall and low fire frequency (Cunningham and Read 2003). Composition shifts both latitudinally and altitudinally with precipitation and temperature, varying predominantly between warm temperate rainforest and subtropical rainforest (Adam 1992; Webb 1959). Likewise, with a change in latitude and altitude there are noticeable changes in the forest understory community dominance from vine to fern to bryophytes (Webb 1978; Kirkpatrick and DellaSala 2011).

Significant terrestrial World Heritage properties within the zone include The Greater Blue Mountains Area (4.8\% of the zone) and the Gondwana Rainforests of Australia (2.31\% of the zone) (DEE 2015). Of relevance to this study, the Gondwana rainforests are recognized by UNESCO for their outstanding universal values (UNESCO 2020):

- significant Geological processes (criterion VIII);

- example of past evolutionary history as well as ongoing evolutionary processes (criterion IX);

- the provision of natural habitat for species of conservation significance (criterion X), including over 270 threatened species).

Whilst the climate varies across the zone, the mean annual temperature is $160 \mathrm{C}$ Celsius, mean maximum of the hottest month is $27.70 \mathrm{C}$ and the mean annual rainfall is $1017.1 \mathrm{~mm}$ (DEE 2015). The climate is warming across the zone and at a greater extent inland, with variable shifts in precipitation (BOM and CSIRO 2020). The Forest Fire Danger Index has increased almost universally across the zone over past decades, with larger increases inland than in coastal areas (Dowdy 2018). 


\section{Methods}

The spatial scope of this study is rainforest vegetation within the EATSF. The temporal scope is the 2019-20 bushfire season (1 July 2019 to 24 February 2020). A range of datasets of varied resolution were utilized in order to map burn severity of rainforest vegetation as well as topographic indices (Table 1).

\section{Burn Severity Mapping}

The Australian Google Earth Engine Burnt Area Map (GEEBAM) is a national database that maps bushfire severity across Australia from 1 July 2019 to $24^{\text {th }}$ of

February 2020 (DAWE 2020). The dataset provides a series of burn severity classes, outlined in Table 2. This dataset is obtained via remote sensing and is not ground-truthed, however, it does utilise calibration with state and territory datasets where available (DAWE 2020). Due to rainforests unique spectral characteristics post-burn, rainforest burn severity was mapped separately from other vegetation types to detect more subtle changes in post-fire vegetation (DAWE 2020).

Table 1. List of all datasets utilised for this study.

\begin{tabular}{|c|c|c|c|}
\hline Dataset & Resolution & Description & Source \\
\hline $\begin{array}{l}\text { GEEBAM } \\
\text { Severity }\end{array}$ & $15 \mathrm{~m}$ & $\begin{array}{l}\text { Utilises spectral signatures from MODIS and Sentinel to map burn severity at a } \\
\text { resolution of } 15 \mathrm{~m} \text {. Calibrated with state burn severity mapping where available } \\
\text { (QLD not calibrated). }\end{array}$ & $\begin{array}{l}\text { Department of } \\
\text { Agriculture, Water and } \\
\text { the Environment (2020) }\end{array}$ \\
\hline $\begin{array}{lr}\text { National } & \text { Vegetation } \\
\text { Information } & \text { System } \\
\text { Version } 5.1 & \end{array}$ & $\begin{array}{l}\text { Resolution } \\
\text { varies } \\
(\sim 30 \mathrm{~m})\end{array}$ & $\begin{array}{l}\text { A vector layer delineating extant native vegetation types across Australia (Major } \\
\text { Vegetation Groups) }\end{array}$ & $\begin{array}{l}\text { Department of } \\
\text { Agriculture, Water and } \\
\text { the Environment (2018) }\end{array}$ \\
\hline $\begin{array}{l}\text { Digital Elevation } \\
\text { Model (DEM) }\end{array}$ & $25 \mathrm{~m}$ Grid & 25 Metre DEM Grid of Australia derived from LiDAR model & $\begin{array}{l}\text { Geoscience } \\
(2015)\end{array}$ \\
\hline
\end{tabular}

Table 2. The Australian Google Earth Engine Burnt Area Map (GEEBAM) Classes and description (DAWE 2020).

\begin{tabular}{|c|c|c|}
\hline $\begin{array}{l}\text { GEEBAM } \\
\text { Value }\end{array}$ & GEEBAM Class & Description \\
\hline 1 & No data & $\begin{array}{l}\text { No data indicates areas outside NIAFED or NVIS categories that do not represent native vegetation (e.g. cleared } \\
\text { land, water) }\end{array}$ \\
\hline 2 & Unburnt & Little or no change observed between pre-fire and post-fire imagery \\
\hline 3 & $\begin{array}{l}\text { Low } \\
\text { Moderate }\end{array}$ & Some change or moderate change detected when compared to reference unburnt areas outside the NIAFED extent \\
\hline 4 & High & Vegetation is mostly scorched \\
\hline 5 & Very high & Vegetation is clearly consumed \\
\hline
\end{tabular}

For statistical analysis within the burn extent, we extended the GEEBAM dataset by a $1 \mathrm{~km}$ buffer, to include potential refugia on the edge of the fire front, a similar buffer size to that of previous studies (Wood et al. 2011). The dataset was then clipped to within the study conservation zone. All No data (1) points were removed from the data analysis.

\section{Vegetation Mapping}

The vegetation dataset utilized is the Australian National Vegetation Information System Version 5.1, which combines a range of higher resolution state and national datasets at a varied resolution of $\sim 30 \mathrm{~m}$. Whilst some alternative state and regional vegetation datasets have a higher resolution, for consistency over state and regional borders, the national dataset has been utilized. The coarseness of this dataset does present concerns for inaccurate identification of rainforest, with the potential to exclude smaller pockets of rainforest refugia; include areas of non-rainforest; or not distinguish important ecotones. The scale of this project has the potential to correct for some of this error, or potentially enhance bias. 
For analysis, the dataset was clipped to the conservation zone and rainforest vegetation was mapped in isolation from other vegetation categories (tropical and sub-tropical rainforest, warm temperate rainforest, dry rainforests and vine thickets and Cool temperate rainforest). For the purpose of this paper, the NVIS category 'tropical or subtropical rainforest' is referred to as 'subtropical rainforest', as tropical rainforests are typically located in latitudes north of the EASTF study area (Adam 1992), Dry rainforest and vine thickets ( $<1 \%$ ) and cool temperate rainforests $(\sim 2 \%)$ were marginal and thus removed from topographic analysis within the burn extent.

The NVIS and GEEBAM datasets were intersected within $\mathrm{R}$ so that rainforest within the GEEBAM and the $1 \mathrm{~km}$ buffer zone contained burn severity values, providing an additional dataset that mapped the burn severity of all rainforest within the $2019-20$ burn extent ( 43\% of Australian rainforest distribution) (RStudio Team 2020).

\section{Terrain}

A national Digital Elevation Model was obtained from Geoscience Australia at a resolution of $30 \mathrm{~m}$, which was then clipped to the conservation zone (Geoscience Australia 2015). From the DEM raster, slope and aspect rasters were calculated utilizing inbuilt QGIS terrain functions, resulting in separate aspect and slope raster layers which covered the entire study area. Topographic Position Index (TPI) was calculated through the QGIS SAGA function (Conrad 2011), which follows the TPI calculation of Guisan et al. (1999). Distance weighting for the $30 \mathrm{~m}$ pixels was set to inverse distance to the power of 1 , with no minimum radius and a maximum radius of $150 \mathrm{~m}$. The inputs were chosen through a visual comparison with terrain layers, so that the output best interpreted obvious ridges and valleys. Due to the scale of the DEM $(\sim 30 \mathrm{~m})$, finer scale topographic refugia is likely not adequately represented by the TPI values.

\section{Sampling Methodology}

100,000 simple random points were generated within the rainforest polygons for the entire conservation zone utilizing R. Each point represents approximately 6 ha of rainforest. Approximately 43,000 of these points fell within the GEEBAM buffer zone, which were then utilized as the primary dataset for analysis of rainforest refugia.

Spatial joins were then performed in QGIS so that each point contained the information for all layers below. Each point thus contains burn severity, NVIS vegetation classification, slope, aspect, TPI and elevation.

\section{Analysis Methodology}

Violin plots with overlaid box and whisker plots were generated for key topographic variables utilizing the ggplot2 package in RStudio (2020). Violin plots were chosen as they can effectively represent spatial data that may not be normally distributed.

Aspect values were converted from degrees to a simple north south bearing, where north represents 0-90 and 270-360, and south represents 90-270 degrees. More precise co-ordinates were also calculated (Supplementary Documents)

Burn extent was calculated as a percentage of points for each sample. Burn percentages was calculated both within the burn extent (encompassing GEEBAM and the $1 \mathrm{~km}$ buffer) and within the entire conservation zone.

\section{Results}

\section{Burn Extent and Severity}

A total of $\sim 100,000$ random points were sampled across the entire zone, encompassing $\sim 630,000$ ha of rainforest, with one sample point per 6ha of rainforest. Of these points, $17 \%$ were burnt, with $13 \%$ to a low and moderate severity, $4 \%$ to a high severity and $1 \%$ to a very high severity (Figure 3). This represents 110,631 ha of burnt rainforest, including 30, 375 ha to a high or very high severity. Within the GEEBAM burn extent and $1 \mathrm{~km}$ buffer, just $58 \%$ of rainforest remained unburnt, with $31 \%$ burned to a low and moderate severity, $9 \%$ to a high severity and $2 \%$ to a very high severity.

Burn extent and severity varied across vegetation types. Dry rainforest or vine thickets vegetation was the most affected by the fires, with $60 \%$ burning to a moderate extent, $10 \%$ burning to a high extent and $4 \%$ burning to a very high extent; with just $27 \%$ remaining unburned within bushfire extent. Subtropical Rainforest and Warm Temperate rainforests retained a similar amount of unburned rainforest (-60\%),

Page $7 / 20$ 
although Subtropical Rainforest burned to a higher low and moderate extent (32\% vs $26 \%$ ) and was slightly less effected by high to very high severity fires ( 10\%) than Warm Temperate Rainforests ( 13\%). This is potentially due to Warm Temperate Rainforests persisting at slightly lower elevations and a wider range of TPI, despite similar slope and aspect mean values (Appendix A). Cool Temperate Rainforest burned to the lowest extent and the lowest severity ( $68 \%$ unburnt). Cool Temperate Rainforest also has the highest proportion on south facing slopes $(75 \%)$ and the highest mean elevation $(-1027 \mathrm{~m})$, despite the highest mean TPI $(0.89)$ and the highest mean slope (25.14). This may highlight the significance of elevation and aspect in determining rainforest distribution within the study area, potentially overriding other topographic variables.

\section{Topography}

Topographic Position Index (TPI), elevation, aspect and slope were analysed for each sample point within the GEEBAM burn extent and $1 \mathrm{~km}$ buffer zone (Figure 4; Figure 5; $\mathrm{n}$ = 42502). Rainforests in low topographic positions, southern aspects, low incline slopes and high elevations were less likely to burn and burned to a lower extent. Rainforests that existed in opposition to these characteristics, were found to be more likely to burn and to a greater severity.

\section{Topographic Position Index}

Topographic Position Index (TPI) influenced burn severity, with a positive trend in TPI correlating with an increase in burn severity. The most noticeable increase was in very high severity burning (mean -0.10), compared to a mean of -0.42 for high severity and -0.75 for low and moderate severity. These results indicate that less sheltered TPI locations (ridges) are more likely to burn at a higher severity than more sheltered locations (valleys). Interestingly, there is no difference between mean values of unburned and low-moderate severity burning (-0.75), indicating that TPI had less influence on the chance of burning than the severity of burning. Mean TPI also increased with elevation, suggesting that at higher elevations topographic position is less necessary for rainforest persistence, presumably due to increased moisture content and decreased temperature.

\section{Elevation}

Mean rainforest elevation varied significantly across burn severity, with a clear positive correlation between elevation and burn severity. The unburned rainforest vegetation mean (meters) was 696.73 , low to moderate was 573.82 , high was 489.24 and very high was 452.34 . This indicates that rainforests at lower elevations were at a greater risk to burning during the 2019-20 bushfire season, with higher severity burning occurring more commonly at lower elevations. This is likely due to higher moisture content and cooler temperatures often associated with higher elevations; both of which are antagonistic to high intensity fire (Ash 1988). The results may also be influenced by elevated montane areas having a greater proximity from urbanization and agriculture and a greater likelihood of protected area status (and associated fire management plan) than lower elevations.

\section{Slope}

Mean rainforest slope also shifts positively with burn severity, although less linearly than elevation. Within the burn extent, rainforest exists predominantly on slopes from 10-30 degrees ( $\bar{x} 18.64 \pm 9.96)$. Unburned vegetation has a significantly lower mean slope (17.25), whereas slope does not vary significantly between burn severity classes, with a slight decrease in the very high severity mean slope (20.22) from low and moderate (20.66) and high (20.56). This indicates that slope may have influenced the likelihood of burning, although less so the severity of the burning (the opposite of the TPI metric). This may be a result of fire having less opportunity to spread laterally on steeper slopes (Ash 1988)

\section{Aspect}

Aspect also influenced the burn extent and severity of rainforest vegetation, with the results indicating that northern aspects are at a greater risk of burning and typically burn to a higher severity than southern aspects. $52.62 \%$ of rainforests on north facing slopes were unburnt compared to $61.60 \%$ on southern slopes. Burnt rainforest vegetation on northern aspects was higher for all burn severity classes than southern aspects. Detailed aspect analysis that includes more definitive cardinal directions (Supplementary Documents) also reveals that north-eastern slopes were most likely to burn and southwestern slopes least likely to burn. Aspect results are inherently linked 
to divergencies in solar radiation, which influences vegetation and soil dryness, hence influencing rainforest fuel flammability (Ash 1988). Wind direction may also be a factor for aspect, potentially influencing temperature shifts, drying of fuels and fire spread.

\section{Qualitative analysis}

Qualitative analysis of the rainforest burn severity, size and shape indicates that burns typically occurred on the borders of rainforests, with severity often declining deeper into the rainforest vegetation (Mapping in Supplementary Documents). Smaller and narrower patches within the burn extent appear to have burned more extensively than larger patches, often leaving no refugia within. Thus, larger and wider rainforest patches were more effective at withstanding surrounding fire to produce an inner protected refugia. Whether this is indeed influenced by the size of the rainforest patch, or just the likelihood of smaller patches burning to a higher percentage requires further statistical analysis.

\section{Discussion}

\section{Burn extent and severity: An early warning sign for rainforest collapse?}

This study theorized that extensive, intense and severe burning of rainforests occurred across the conservation zone during the 2019-20 bushfire season, which is supported by the results. Approximately $17 \%(\sim 110,000 \mathrm{ha})$ of all rainforests encountered fire, varying in severity from low and moderate ( 13\%), to high $(\sim 4 \%)$ and very high $(\sim 1 \%)$. Burn extent across key vegetation categories 'subtropical rainforest' and 'warm temperate rainforest' was alike $(\sim 17 \%)$, although warm temperate rainforest burned marginally more severely. Within the burn extent and $1 \mathrm{~km}$ buffer the overall likelihood of rainforest burning was $\sim 42 \%$, with $~ 31 \%$ of burnt rainforest occurring at a low and moderate severity, $\sim 9 \%$ at a high severity and $\sim 2 \%$ at a very high severity. This demonstrates the ferocity of the 2019-20 bushfires in eastern Australia, supporting evidence of drought and high intensity fire weakening typically fire-resistant rainforest refugia (Collins et al 2019).

The resilience of these rainforests to extensive burning of varied severity is difficult to determine. Rainforests have the capacity to recover from low to moderate severity burning, however, this severity of burning also has the capacity to reduce rainforest resilience to recurrent fire and pioneer invasion (Hjerpe et al. 2001; Cochrane and Schulze 1999). Upon field assessment, we may even find that the inherent nature of aerial analysis has concealed high severity burning within the rainforest subcanopy (Meddens et al. 2018). The extent of severe rainforest burning is particularly alarming, with high severity burning rare in most rainforest environments (Cochrane 2003; Williams et al. 2012). There is a chance that areas of rainforest burnt to a high severity may be at risk of shifting to a new state, especially where canopy cover is reduced, enabling shade intolerant pioneer species to invade (Murphy and Bowman 2012). As demonstrated by Fletcher et al. (2014), burned rainforests bordered by pyrophytic communities are at a particularly high risk of pioneer invasion and should be closely monitored (Cadd et al. 2019). The resilience of older individual rainforest trees will also be critical for maintaining a seed source for post fire recovery (Hoffman et al. 2018).

With future meteorological forecasts predicting an increase in fire weather and droughts for eastern Australia, we are likely to see more frequent high intensity fire events (Bowman et al 2020; Dowdy 2018). Recurrent fire is a particularly threatening process for rainforests, with the potential to enact positive feedback mechanisms in which rainforest that is in the early post-fire successional stages (subclimax) is more vulnerable to, and at a higher risk of, burning more frequently and more severely (Cochrane and Schulze 1999). Pioneer species that have infiltrated rainforests following the 2019-20 season may promote and enhance follow up fires within the rainforest burn extent, irrespective of future climatic shifts (Cochrane and Schulze 1999). Further drought over the coming years and perhaps decades is also likely to inhibit rainforest recovery (Harvey et al. 2016; Tepley et al. 2017; Littlefield 2019). Recurrent fires and single severe fire events both have the potential to shift rainforest to a new state (Fletcher et al. 2020; Bradstock et al. 2002; Cochrane and Schulze 1999), therefore it is vital that we monitor these systems for signs of catastrophic failure (Scheffer et al. 2012). Concerningly, early warning signals of catastrophic failure are not always detectible, meaning that we may be unable to tell if a rainforest is on the verge of a critical transition until collapse is imminent (Scheffer et al. 2012). The severity of the 2019-20 season may be a false alarm for a system that is highly resilient to climate change, or it may be an early warning sign of a system at risk of widespread collapse.

\section{Rainforest Refugia}


This study found that unburnt rainforests in mid-eastern Australia during the 2019-20 bushfire season shared similar topographic fire refugia characteristics to that of rainforests in south-eastern Australia (Holz et al. 2020; Wood et al. 2011; Collins et al. 2019), tropical north-eastern Australia (Ash 1988) and globally (Krawchuk et al. 2016), reflecting the fire rainforest antagonism described by Wood et al. (2011). This study found that rainforests on northern aspects, lower elevations, steeper slopes and ridges burned more intensely and to a greater extent, with the opposing topographic features more likely to act as fire refugia for rainforests. Furthermore, the study found that rainforest generally occupied mesic topographic features, such as southern aspects, to a greater extent than northern aspects, likely a result of favourable climatic conditions for rainforests and reduced fire potential. Despite research pointing to the muted effects of topography in severe drought fuelled fire weather in south-eastern Australia (Collins et al. 2019), this data indicates that topography is a crucial component of rainforest resilience to high intensity drought fuelled fire in mid-eastern Australia. Importantly, the cooler and wetter climatic conditions of mesic topographic locations should improve rainforest recovery outcomes post-fire (Harvey et al. 2016; Dodson and Root 2013).

Elevation appears to be a critical component of burn severity and extent, with elevation negatively correlated with burn severity. This is likely a reflection of a higher moisture content and lower temperature in montane environments of eastern Australia (Reside et al 2013). Studies have found high levels of endemism in eastern Australian montane regions (Weber et al. 2014; Reside et al. 2013) indicating that their climatic diversity provides critical refugia for species and communities to retreat to in times of warming temperatures and increasing aridity. This is reflected in the negative elevation and burn severity gradient of this study. Importantly, post-fire recovery outcomes can improve with increased elevation (Dodson and Root 2013). As a result, we can assume that higher elevation rainforests will be critical rainforest refugia following the 2019-20 bushfire season and in a more fire prone climate, particularly elevated areas that are reinforced with other topographic features (Dobrowski 2011).

Qualitative analysis of the mapping demonstrates that bushfire often, although not universally, diminished in severity with inward progression into larger rainforests. As a result, there appears to be a rainforest-fire buffer, in which fire diminishes as it penetrates the fireresistant vegetation. This is obvious when we consider that rainforest produces a microclimate that suppresses fire propagation (Cochrane 2003), with larger rainforests better equipped to progressively suppress fire as it advances into the mesic environment, simultaneously minimising spot fire propagation. It is also likely that larger rainforests more frequently exist in locations that have more favourable climatic conditions and reduced fire occurrence. Thus, larger rainforest systems may be more likely to provide refugia that lies deeper within the rainforest perimeter. This may also be important for enabling post fire recovery, where rainforest refugia retains the reproductive capacity and genetic diversity for re-expansion under more favourable conditions (Williams et al. 2012). Conversely, smaller patches that burn completely may be more likely to undergo a transition to a new state.

\section{Conclusions}

This observational study indicates that topographic features, moisture and rainforest size did influence the severity of rainforest burning in the study area during the 2019-20 season. As a result, we conclude that topographic features such as elevation, aspect, topographic position and slope are important for rainforest fire refugia in eastern Australia, even under extreme fire weather and severe drought. The research further supports evidence that rainforests located at higher elevations, less angular slopes, poleward aspects, within valleys and in larger patches may be more likely to persist during drought fuelled bushfire events. As a result, rainforests fitting these topographic and spatial criteria may play a crucial refugia role in biodiversity perseverance during anthropogenic climate change (Meddens et al. 2018).

The study also reveals the broad extent to which rainforests did burn during the bushfire season ( 17\%). Areas that burned to a high and very high severity $(\sim 5 \%)$ may be at the greatest risk of shifting to an alternate stable state and should be further investigated, particularly regarding the influence of surrounding vegetation. It is difficult to determine how mid-eastern Australian rainforests will respond to the extensive low and moderate severity burning, with recurrent fire events likely to test the resilience of these fire sensitive systems.

With forecasts for further positive shifts in bushfire severity, bushfire frequency and drought, rainforests may be at risk of rapid distribution and biodiversity declines (Bowman et al. 2020; BOM and CSIRO 2020). The consequences may be enormous, with potential for widespread species extinction and massive declines in biodiversity, a reduction in ecosystem services and the potential to positively influence an already warming climate, leading to compounding bushfire events and escalating rainforest declines (Corlett 2016; Seidl et al. 2016; Bowman et al. 2020; Aragão et al. 2018). As persistent rainforest fire refugia is critical for the retention of genetic diversity and the protection of threatened species during climatic change (Reside et al. 2013), further research must address its potential and its limitations in order to implement adaptation and mitigation strategies to improve rainforest resilience and avoid rapid decline. 
Due to the broad scale and non-ground validated nature of the datasets, all results should be considered as a broad scale estimate, designed primarily as an instigator of more focused research. Future research should consider higher resolution and field validated data.

\section{Declarations}

\section{Acknowledgments}

This paper acknowledges the traditional custodians of this land and pays respects to their Elders past and present. Traditional bushfire management has shaped Australia's vegetation in ways contemporary scientific knowledge can never fully comprehend.

This project would not have been possible without the availability of the GEEBAM mapping product provided by the Department of Agriculture, Water and the Environment in collaboration with Remote Sensing and Landscape Science Branch, Science Economics and Insights Division, New South Wales Department of Planning, Industry and Environment and the University of NSW. Federally funded mapping products such as this enable research that transcends traditional state and regional boundaries and is vital for cost and time limited desktop research such as this.

This paper also acknowledges the School of Earth and Environmental Science at the University of Queensland, through which the initial research project was undertaken.

\section{Supplementary Information}

The supplementary documents and data supporting the conclusions are available via the Dropbox repository, https://www.dropbox.com/s/cvtu8mbwpu58q5u/Bennell\%2C\%20Stewart\%2C\%20Moss\%202020\%20Supplementary\%20Documents.zip? $\mathrm{dl}=0$.

\section{Authors Contributions}

MB undertook the study design, original draft, manuscript development and data analysis. PS provided extensive feedback during research development and analysis, investigation on rainforest vegetation as well as extensive editing and research. PM provided extensive editing and investigation, with contributions to the background focusing on palaeoecological fire-rainforest interactions. All authors read and approved the final manuscript.

\section{Availability of data and materials}

The data sets used or analysed during this study are available from the corresponding author on reasonable request.

The public datasets supporting the conclusions of this article are described and referenced in Table 1.

\section{Funding}

No funding was utilised for this paper.

\section{Ethics approval and consent to participate}

Not applicable.

\section{Consent for publication}

Not applicable.

\section{Competing interests}


The authors declare that they have no competing interests.

\section{References}

Adam, Paul. 1992. Australian rainforests. Oxford University Press.

Aragão, Luiz E. O. C., Liana O. Anderson, Marisa G. Fonseca, Thais M. Rosan, Laura B. Vedovato, Fabien H. Wagner, Camila V. J. Silva, Celso H. L. Silva Junior, Egidio Arai, Ana P. Aguiar, Jos Barlow, Erika Berenguer, Merritt N. Deeter, Lucas G. Domingues, Luciana Gatti, Manuel Gloor, Yadvinder Malhi, Jose A. Marengo, John B. Miller, Oliver L. Phillips, and Sassan Saatchi. 2018. 21st Century droughtrelated fires counteract the decline of Amazon deforestation carbon emissions. Nature Communications 9 (1): 536.

https://doi.org/10.1038/s41467-017-02771-y.

Ash, J. 1988. The Location and Stability of Rainforest Boundaries in North-Eastern Queensland, Australia. Journal of Biogeography 15 (4): 619-630. http://www.jstor.org/stable/2845440.

Baker, Andrew, and Claudia Catterall. 2015. Where has all the fire gone? Quantifying the spatial and temporal extent of fire exclusion in Byron Shire, Australia. Ecological Management \& Restoration 16. https://doi.org/10.1111/emr.12161.

Baker, Andrew G., Claudia Catterall, Kirsten Benkendorff, and Rod J. Fensham. 2020a. Rainforest expansion reduces understorey plant diversity and density in open forest of eastern Australia. Austral Ecology 45 (5): 557-571. https://doi.org/10.1111/aec.12871.

Baker, Andrew G., Claudia Catterall, Kirsten Benkendorff, and Bradley Law. 2020b. No room to move: bat response to rainforest expansion into long-unburnt eucalypt forest. Pacific Conservation Biology.

https://doi.org/https://doi.org/10.1071/PC19045.

Bellwood, D. R., T. P. Hughes, C. Folke, and M. Nyström. 2004. Confronting the coral reef crisis. Nature 429 (6994): 827-833.

https://doi.org/10.1038/nature02691.

Bureau of Meteorology (BOM). 2019. Special Climate Statement 72-dangerous bushfire weather in spring 2019. Australian Bureau of Meterology. http://www.bom.gov.au/climate/current/statements/scs72.pdf

Bureau of Meteorology and Commonwealth Scientific and Industrial Research Organisation (BOM and CSIRO). 2020. State of the Climate 2020. Australian Bureau of Meteorology. http://www.bom.gov.au/state-of-the-climate/documents/State-of-the-Climate-2020.pdf.

Bowman, David M. J. S. 2005. Understanding a Flammable Planet: Climate, Fire and Global Vegetation Patterns. The New Phytologist 165 (2): 341-345. http://www.jstor.org/stable/1514716.

Bowman, David M. J. S., Crystal A. Kolden, John T. Abatzoglou, Fay H. Johnston, Guido R. van der Werf, and Mike Flannigan. 2020. Vegetation fires in the Anthropocene. Nature Reviews Earth \& Environment 1 (10): 500-515. https://doi.org/10.1038/s43017-020-0085-3. https://doi.org/10.1038/s43017-020-0085-3.

Bowman, David M. J. S. 2000. Australian rainforests: islands of green in a land of fire. Cambridge University Press.

Bowman, David M. J. S. 1991. Recovery of some northern Australian monsoon forest tree species following fire. Proceedings of the Royal Society of Queensland. vol. 101, pp. 21-25.

Bradstock, Ross A, Jann E Williams, and Malcolm A Gill. 2002. Flammable Australia: the fire regimes and biodiversity of a continent. Cambridge University Press.

Butler, Don W., Roderick J. Fensham, Brett P. Murphy, Simon G. Haberle, Sarah J. Bury, and David M. J. S. Bowman. 2014. Aboriginemanaged forest, savanna and grassland: biome switching in montane eastern Australia. Journal of Biogeography 41 (8): 1492-1505.

https://doi.org/10.1111/jbi.12306. https://doi.org/10.1111/jbi.12306.

Cadd, Haidee, Michael-Shawn Fletcher, Michela Mariani, Hendrik Heijnis, and Patricia S. Gadd. 2019. The influence of fine-scale topography on the impacts of Holocene fire in a Tasmanian montane landscape. Journal of Quaternary Science 34 (7): 491-498.

Page 12/20 
https://doi.org/https://doi.org/10.1002/jqs.3114.

Cary, Geoffrey J, Ross A Bradstock, A Malcolm Gill, and Richard J Williams. 2012. Global change and fire regimes in Australia. CSIRO Publishing: Collingwood, VIC, Canada.

Cochrane, Mark A., and Mark D. Schulze. 1999. Fire as a Recurrent Event in Tropical Forests of the Eastern Amazon: Effects on Forest Structure, Biomass, and Species Composition. Biotropica 31 (1): 2-16.

https://doi.org/10.1111/j.1744-7429.1999.tb00112.x.

Cochrane, Mark A. 2003. Fire science for rainforests. Nature 421 (6926): 913-919. https://doi.org/10.1038/nature01437.

Collins, Luke, Andrew F. Bennett, Steve W. J. Leonard, and Trent D. Penman. 2019. Wildfire refugia in forests: Severe fire weather and drought mute the influence of topography and fuel age. Global Change Biology 25 (11): 3829-3843. https://doi.org/10.1111/gcb.14735.

Conrad, O. 2011, Module Topographic Position Index, http://www.saga-gis.org/saga_tool_doc/2.2.1/ta_morphometry_18.html

Corlett, R. T. 2016. Tropical Rainforests and Climate Change. In Reference Module in Earth Systems and Environmental Sciences. Elsevier.

Couper, Patrick, and Conrad Hoskin. 2008. Litho-refugia: the importance of rock landscapes for the long-term persistence of Australian rainforest fauna. Australian Zoologist 34 (4): 554-560.

https://doi.org/10.7882/AZ.2008.032.

Cunningham, Shaun C., and Jenny Read. 2003. Do temperate rainforest trees have a greater ability to acclimate to changing temperatures than tropical rainforest trees?. New Phytologist 157, no. 1: 55-64.

Department of Agricilture Water and the Environment (DAWE). 2020. Australian Google Earth Engine Burnt Area Map, A Rapid, National Approach to Fire Severity Mapping. edited by Water and the Environment Department of Agriculture: Australian Government.

http://www.environment.gov.au/fed/catalog/search/resource/details.page?uuid=\%7B8CE7D6BE-4A82-40D7-80BC-647CB1FE5C08\%7D.

Department of Agriculture, Water and the Environment (DAWE). 2018. National Vegetation Information System (NVIS) Version 5.1 Australia - Extant Vegetation. Department of Agriculture, Water and the Environment, Canberra.

https://www.environment.gov.au/land/native-vegetation/national-vegetation-information-system.

Department of Environment and Energy (DEE). 2015. Conservation Management Zones of Australia, Eastern Australia Temperate and Subtropical Forests. edited by Department of the Environment and Energy: Autralian Government.

https://www.environment.gov.au/system/files/resources/0e25a516-df10-45b4-8122-5f78a2a2b342/files/cmz-eastern-australiatemperate-subtropical-forests.pdf.

Dobrowski, Solomon Z. 2011. A climatic basis for microrefugia: the influence of terrain on climate. Global Change Biology 17 (2): $1022-$ 1035.

https://doi.org/https://doi.org/10.1111/j.1365-2486.2010.02263.x.

Dodson, Erich Kyle, and Heather Taylor Root. 2013. Conifer regeneration following stand-replacing wildfire varies along an elevation gradient in a ponderosa pine forest, Oregon, USA. Forest Ecology and Management 302: 163-170.

https://doi.org/https://doi.org/10.1016/j.foreco.2013.03.050.

Dodson, J. R., P. W. Greenwood, and R. L. Jones. 1986. Holocene forest and wetland vegetation dynamics at Barrington Tops, New South Wales. Journal of Biogeography: 561-585.

Donders, Timme H., Simon G. Haberle, Geoffrey Hope, Friederike Wagner, and Henk Visscher. 2007. Pollen evidence for the transition of the Eastern Australian climate system from the post-glacial to the present-day ENSO mode. Quaternary Science Reviews 26, no. 11-12: 1621-1637. 
Donders, Timme H., Friederike Wagner-Cremer, and Henk Visscher. 2008. Integration of proxy data and model scenarios for the midHolocene onset of modern ENSO variability. Quaternary Science Reviews 27, no. 5-6: 571-579.

Fensham, R. J., and R. J. Fairfax. 2006. Can burning restrict eucalypt invasion on grassy balds?. Austral Ecology 31, no. 3: $317-325$.

https://doi.org/10.1111/j.1442-9993.2006.01560.x.

Fensham R. J. \& Fairfax R. J. 1996. The disappearing grassy balds of the Bunya Mountains, south-eastern Queensland. Aust. J. Bot. 44, 543-58.

Filkov, Alexander I., Tuan Ngo, Stuart Matthews, Simeon Telfer, and Trent D. Penman. 2020. Impact of Australia's catastrophic 2019/20 bushfire season on communities and environment. Retrospective analysis and current trends. Journal of Safety Science and Resilience 1 (1): 44-56. https://doi.org/https://doi.org/10.1016/j.jnlssr.2020.06.009.

Fletcher, M. S., D. M. J. S. Bowman, C. Whitlock, M. Mariani, and L. Stahle. 2018. The changing role of fire in conifer-dominated temperate rainforest through the last 14,000 years. Quaternary Science Reviews 182: 37-47.

https://doi.org/https://doi.org/10.1016/j.quascirev.2017.12.023.

Fletcher, Michael-Shawn, Haidee R. Cadd, Michela Mariani, Tegan L. Hall, and Samuel W. Wood. 2020. The role of species composition in the emergence of alternate vegetation states in a temperate rainforest system. Landscape Ecology. https://doi.org/10.1007/s10980-02001110-9.

Fletcher, Michael-Shawn, and lan Thomas. 2010. The origin and temporal development of an ancient cultural landscape. Journal of Biogeography 37 (11): 2183-2196. https://doi.org/10.1111/j.1365-2699.2010.02363.x.

Fletcher, Michael-Shawn, Sam W Wood, and Simon G Haberle. 2014. A fire-driven shift from forest to non-forest: evidence for alternative stable states? Ecology 95 (9): 2504-2513.

Fonseca, Marisa Gesteira, Lincoln Muniz Alves, Ana Paula Dutra Aguiar, Egidio Arai, Liana Oighenstein Anderson, Thais Michele Rosan, Yosio Edemir Shimabukuro, and Luiz Eduardo Oliveira e Cruz de Aragão. 2019. Effects of climate and land-use change scenarios on fire probability during the 21st century in the Brazilian Amazon. Global Change Biology 25 (9): 2931-2946.

https://doi.org/10.1111/gcb.14709.

Foreman, Paul W. 2017. A framework for testing the influence of Aboriginal burning on grassy ecosystems in lowland, mesic southeastern Australia. Australian Journal of Botany 64, no. 8: 626-642.

https://doi.org/10.1071/BT16081.

Geoscience Australia. 2015. Digital Elevation Model (DEM) 25 Metre Grid of Australia derived from LiDAR. 2015. Geoscience Australia, Canberra. http://dx.doi.org/10.4225/25/5653D877D3E08.

Guisan, Antoine, Stuart B. Weiss, and Andrew D. Weiss. 1999. GLM versus CCA spatial modeling of plant species distribution. Plant Ecology 143 (1): 107-122. https://doi.org/10.1023/A:1009841519580.

Harvey, Brian J., Daniel C. Donato, and Monica G. Turner. 2016. High and dry: post-fire tree seedling establishment in subalpine forests decreases with post-fire drought and large stand-replacing burn patches. Global Ecology and Biogeography 25 (6): $655-669$.

https://doi.org/10.1111/geb.12443. https://doi.org/10.1111/geb.12443.

Hjerpe, Johan, Henrik Hedenas, and Thomas Elmqvist. 2001. Tropical Rain Forest Recovery from Cyclone Damage and Fire in Samoa1. Biotropica 33 (2): 249-259. https://doi.org/10.1111/j.1744-7429.2001.tb00176.x.

Hoffman, Kira M., Andrew J. Trant, Wiebe Nijland, and Brian M. Starzomski. 2018. Ecological legacies of fire detected using plot-level measurements and LiDAR in an old growth coastal temperate rainforest. Forest Ecology and Management 424: 11-20.

https://doi.org/https://doi.org/10.1016/j.foreco.2018.04.020.

Page $14 / 20$ 
Hoffmann, William A., Ryan Adasme, M. Haridasan, Marina T. de Carvalho, Erika L. Geiger, Mireia A. B. Pereira, Sybil G. Gotsch, and Augusto C. Franco. 2009. Tree topkill, not mortality, governs the dynamics of savanna-forest boundaries under frequent fire in central Brazil. Ecology 90 (5): 1326-1337. https://doi.org/10.1890/08-0741.1.

Hoffmann, William A., Erika L. Geiger, Sybil G. Gotsch, Davi R. Rossatto, Lucas C. R. Silva, On Lee Lau, M. Haridasan, and Augusto C. Franco. 2012. Ecological thresholds at the savanna-forest boundary: how plant traits, resources and fire govern the distribution of tropical biomes. Ecology Letters 15 (7): 759-768. https://doi.org/10.1111/j.1461-0248.2012.01789.x.

Hoffmann, William A., and Otto T. Solbrig. 2003. The role of topkill in the differential response of savanna woody species to fire. Forest Ecology and Management 180 (1): 273-286.

https://doi.org/10.1016/S0378-1127(02)00566-2.

Holz, Andrés, Sam W. Wood, Carly Ward, Thomas T. Veblen, and David M. J. S. Bowman. 2020. Population collapse and retreat to fire refugia of the Tasmanian endemic conifer Athrotaxis selaginoides following the transition from Aboriginal to European fire management. Global Change Biology 26 (5): 3108-3121. https://doi.org/10.1111/gcb.15031.

Keppel, Gunnar, Kimberly P. Van Niel, Grant W. Wardell-Johnson, Colin J. Yates, Margaret Byrne, Ladislav Mucina, Antonius G. T. Schut, Stephen D. Hopper, and Steven E. Franklin. 2012. Refugia: identifying and understanding safe havens for biodiversity under climate change. Global Ecology and Biogeography 21 (4): 393-404.

https://doi.org/10.1111/j.1466-8238.2011.00686.x.

Kirkpatrick, James B., and Dominick A. DellaSala. 2011. Temperate rainforests of Australasia. In Temperate and Boreal Rainforests of the World: Ecology and Conservation, pp. 195-212. Island Press, Washington, DC.

Krawchuk, Meg A., Sandra L. Haire, Jonathan Coop, Marc-André Parisien, Ellen Whitman, Geneva Chong, and Carol Miller. 2016. Topographic and fire weather controls of fire refugia in forested ecosystems of northwestern North America. Ecosphere 7 (12): e01632.

https://doi.org/10.1002/ecs2.1632.

Lindenmayer, David B., Richard J. Hobbs, Gene E. Likens, Charles J. Krebs, and Samuel C. Banks. 2011. Newly discovered landscape traps produce regime shifts in wet forests. Proceedings of the National Academy of Sciences 108 (38): 15887-15891. https://doi.org/10.1073/pnas.1110245108.

Littlefield, Caitlin E. 2019. Topography and post-fire climatic conditions shape spatio-temporal patterns of conifer establishment and growth. Fire Ecology 15 (1): 34. https://doi.org/10.1186/s42408-019-0047-7.

Mark, G. L. van Nieuwstadt, Douglas Sheil, and Kuswata Kartawinata. 2001. The Ecological Consequences of Logging in the Burned Forests of East Kalimantan, Indonesia. Conservation Biology 15 (4): 1183-1186. http://www.jstor.org/stable/3061339.

Meddens, Arjan J H, Crystal A Kolden, James A Lutz, Alistair M S Smith, C Alina Cansler, John T Abatzoglou, Garrett W Meigs, William M Downing, and Meg A Krawchuk. 2018. Fire Refugia: What Are They, and Why Do They Matter for Global Change? BioScience 68 (12): $944-$ 954. https://doi.org/10.1093/biosci/biy103.

Millar, Constance I., and Nathan L. Stephenson. 2015. Temperate forest health in an era of emerging megadisturbance. Science 349 (6250): 823. https://doi.org/10.1126/science.aaa9933.

Moravek, Silvie, Jon Luly, John Grindrod, and Russell Fairfax. 2013. The origin of grassy balds in the Bunya Mountains, southeastern Queensland, Australia. The Holocene 23, no. 2: 305-315.

https://doi.org/10.1177/0959683612460792.

Moss, Patrick T, John Tibby, Lynda Petherick, Hamish McGowan, and Cameron Barr. 2013. Late Quaternary vegetation history of North Stradbroke Island, Queensland, eastern Australia. Quaternary Science Reviews 74: 257-272.

Murphy, Brett P., and David M. J. S. Bowman. 2012. What controls the distribution of tropical forest and savanna? Ecology Letters 15 (7): 748-758. https://doi.org/10.1111/j.1461-0248.2012.01771.x.

Page 15/20 
Nolan, Rachael H., Matthias M. Boer, Luke Collins, Víctor Resco de Dios, Hamish Clarke, Meaghan Jenkins, Belinda Kenny, and Ross A. Bradstock. 2020b. Causes and consequences of eastern Australia's 2019-20 season of mega-fires. Global Change Biology 26 (3): $1039-$ 1041. https://doi.org/10.1111/gcb.14987.

Phillips, Nicky, and Bianca Nogrady. 2020. The climate link to Australia's fires. Nature 577 (7792): 610-612.

Reside, April E, Jeremy VanDerWal, Ben L Phillips, Luke P Shoo, Dan F Rosauer, Barbara J Anderson, Justin A Welbergen, Craig Moritz, Simon Ferrier, Thomas D Harwood, KJ Williams, B Mackey, S Hugh, YM Williams, and SE Williams. 2013. Climate change refugia for terrestrial biodiversity: Defining areas that promote species persistence and ecosystem resilience in the face of global climate change. (National Climate Change Adaptation Research Facility, Gold Coast, Queensland). https://www.nccarf.edu.au/publications/climatechange-refugia-terrestrial-biodiversity.

Rosier, S. H. R., R. Reese, J. F. Donges, J. De Rydt, G. H. Gudmundsson, and R. Winkelmann. 2020. The tipping points and early-warning indicators for Pine Island Glacier, West Antarctica. The Cryosphere Discussions: 1-23. https://doi.org/10.5194/tc-2020-186.

RStudio Team. 2020. RStudio: Integrated Development for R. RStudio, PBC, Boston, MA. http://www.rstudio.com/.

Sanderson, Benjamin M., and Rosie A. Fisher. 2020. A fiery wake-up call for climate science. Nature Climate Change 10 (3): 175-177. https://doi.org/10.1038/s41558-020-0707-2.

Scheffer, M., S. R. Carpenter, T. M. Lenton, J. Bascompte, W. Brock, V. Dakos, J. Van De Koppel, I. A. Van De Leemput, S. A. Levin, E. H. Van Nes, M. Pascual, and J. Vandermeer. 2012. Anticipating critical transitions. Science 338 (6105): 344-348.

https://doi.org/10.1126/science.1225244.

Seidl, Rupert, Thomas A. Spies, David L. Peterson, Scott L. Stephens, and Jeffrey A. Hicke. 2016. REVIEW: Searching for resilience: addressing the impacts of changing disturbance regimes on forest ecosystem services. Journal of Applied Ecology 53 (1): 120-129. https://doi.org/10.1111/1365-2664.12511.

Staver, A. Carla, Sally Archibald, and Simon Levin. 2011. Tree cover in sub-Saharan Africa: Rainfall and fire constrain forest and savanna as alternative stable states. Ecology 92 (5): 1063-1072. https://doi.org/10.1890/10-1684.1.

Stewart, Philip. 2017. Changing Fire Regimes in Tropical and Subtropical Australia. The University of Queensland, School of Earth and Environmental Sciences.

Stewart, Philip Le CF, and Patrick T Moss. 2015. Fire patterns of South Eastern Queensland in a global context: A review. In: Keane, Robert E.; Jolly, Matt; Parsons, Russell; Riley, Karin. Proceedings of the large wildland fires conference, May 19-23, 2014; Missoula, MT. Proc. RMRS-P-73. Fort Collins, CO: US Department of Agriculture, Forest Service, Rocky Mountain Research Station. p. 227-236.

Tepley, A, T Veblen, G Perry, G Stewart, and C Naficy. 2016. Positive feedbacks to fire-driven deforestation following human colonization of the South Island of New Zealand. Ecosystems 19 (8): 1325-1344.

Tepley, Alan J., Jonathan R. Thompson, Howard E. Epstein, and Kristina J. Anderson-Teixeira. 2017. Vulnerability to forest loss through altered postfire recovery dynamics in a warming climate in the Klamath Mountains. Global Change Biology 23 (10): 4117-4132.

https://doi.org/10.1111/gcb.13704.

UNESCO. 2020. Gondwana Rainforests of Australia. United Nations Educational, Scientific and Cultural Organisation. Accessed 01 November 2020. https://whc.unesco.org/en/list/368/.

van Oldenborgh, G. J., F. Krikken, S. Lewis, N. J. Leach, F. Lehner, K. R. Saunders, M. van Weele, K. Haustein, S. Li, D. Wallom, S. Sparrow, J. Arrighi, R. P. Singh, M. K. van Aalst, S. Y. Philip, R. Vautard, and F. E. L. Otto. 2020. Attribution of the Australian bushfire risk to anthropogenic climate change. Nat. Hazards Earth Syst. Sci. Discuss. 2020: 1-46. https://doi.org/10.5194/nhess-2020-69.

Wagner, Till J. W., and lan Eisenman. 2015. False alarms: How early warning signals falsely predict abrupt sea ice loss. Geophysical Research Letters 42 (23): 10,333-10,341.

https://doi.org/10.1002/2015GL066297. 
Webb, L. J. 1978. A structural comparison of New Zealand and south-east Australian rain forests and their tropical affinities. Australian journal of ecology 3, no. 1: 7-21.

Webb L. J. 1964. An historical interpretation of the grass balds of the Bunya Mountains, south Queensland. Ecology 45, 159-62.

Webb, L. J. 1959. A Physiognomic Classification of Australian Rain Forests. Journal of Ecology 47, no. 3: 551-70.

https://doi.org/10.2307/2257290.

Weber, Lui C., Jeremy VanDerWal, Susanne Schmidt, William J. F. McDonald, and Luke P. Shoo. 2014. Patterns of rain forest plant endemism in subtropical Australia relate to stable mesic refugia and species dispersal limitations. Journal of Biogeography 41 (2): $222-$ 238. https://doi.org/10.1111/jbi.12219.

Williams, Paul. 2000. Fire-stimulated rainforest seedling recruitment and vegetative regeneration in a densely grassed wet sclerophyll forest of north-eastern Australia. Australian Journal of Botany - AUST J BOT 48. https://doi.org/10.1071/BT99020.

Williams, Richard J., Ross A. Bradstock, and A. Malcolm Gill. 2012. Flammable Australia : Fire Regimes, Biodiversity and Ecosystems in a Changing World. Victoria, AUSTRALIA: CSIRO Publishing.

Wood, Sam W., Brett P. Murphy, and David M. J. S. Bowman. 2011. Firescape ecology: how topography determines the contrasting distribution of fire and rain forest in the south-west of the Tasmanian Wilderness World Heritage Area. Journal of Biogeography 38 (9): 1807-1820. https://doi.org/10.1111/j.1365-2699.2011.02524.x.

\section{Figures}

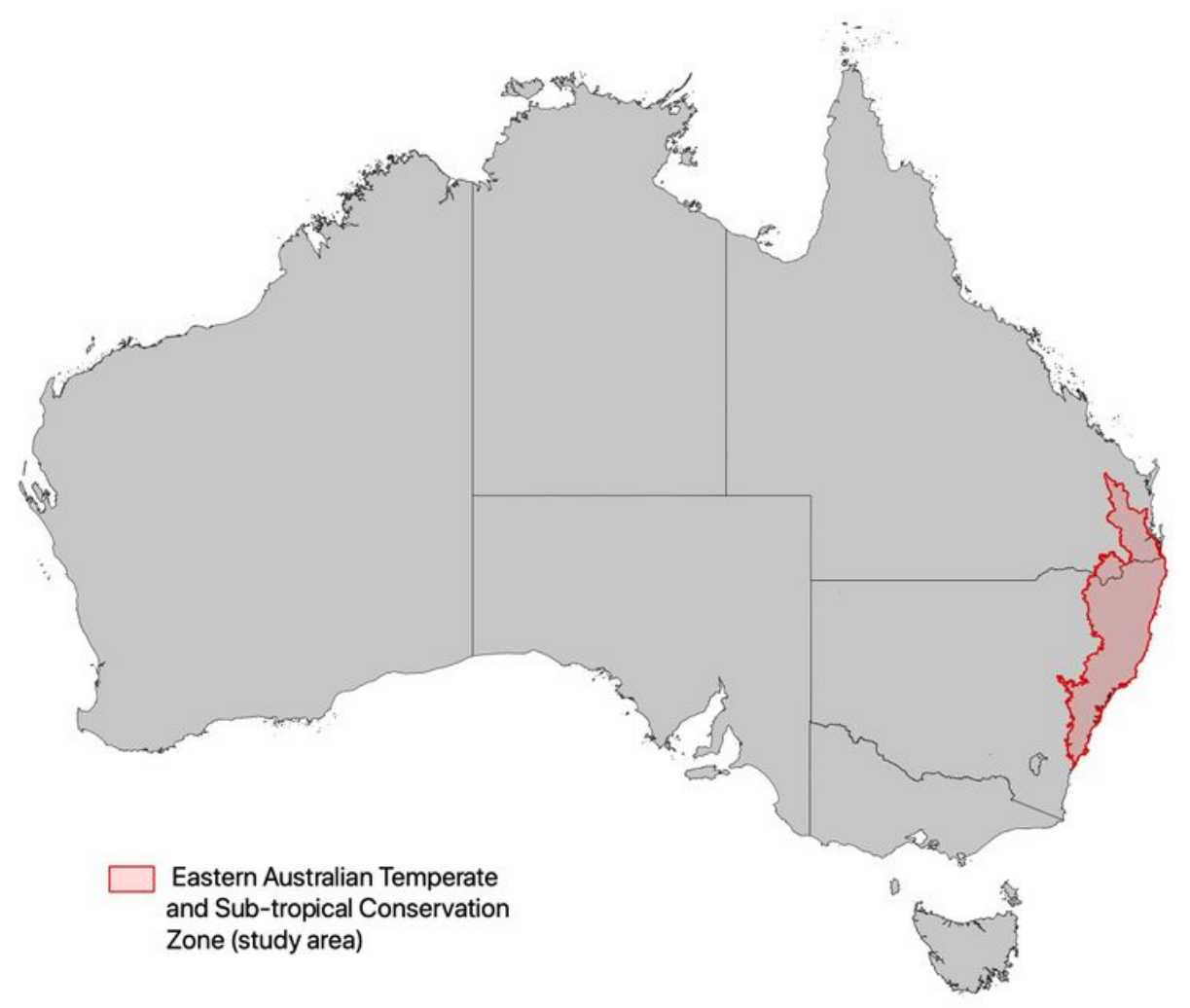

Figure 1 


\section{Distribution of Major Rainforest Vegetation Groups}

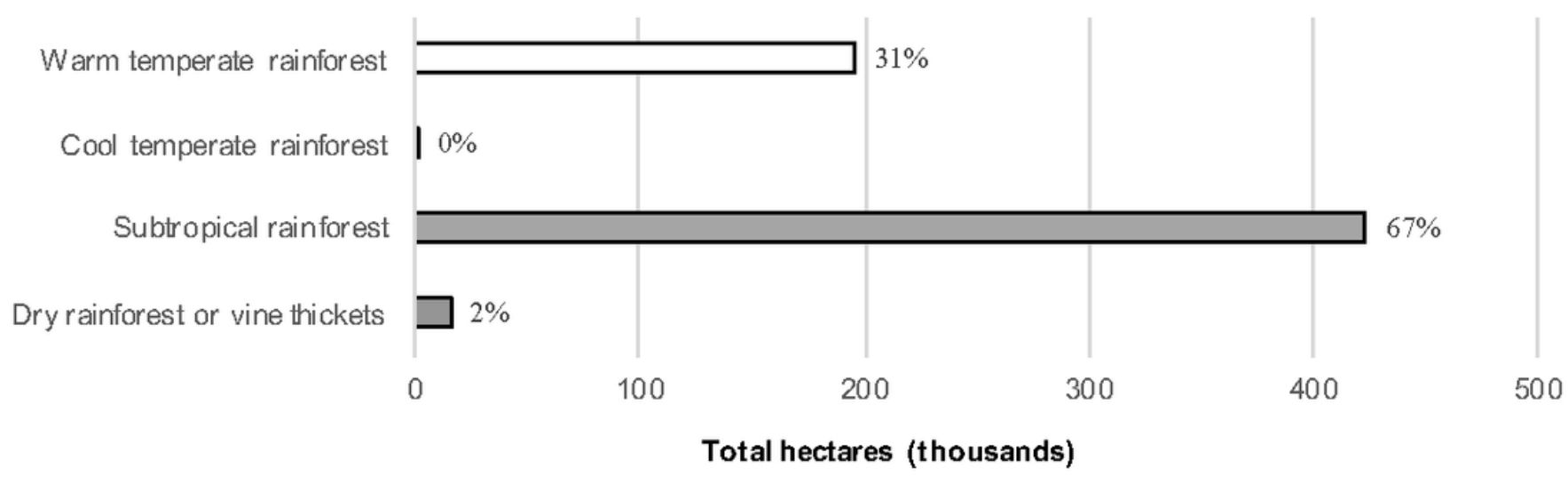

\section{Figure 2}

Distribution of Major rainforest vegetation groups within the Eastern Australian Temperate and Subtropical Forests Conserva-tion Management Zone study area. Calculated by the authors in 2020 with the National Vegetation Information System dataset (NVIS Technical Working Group 2017).

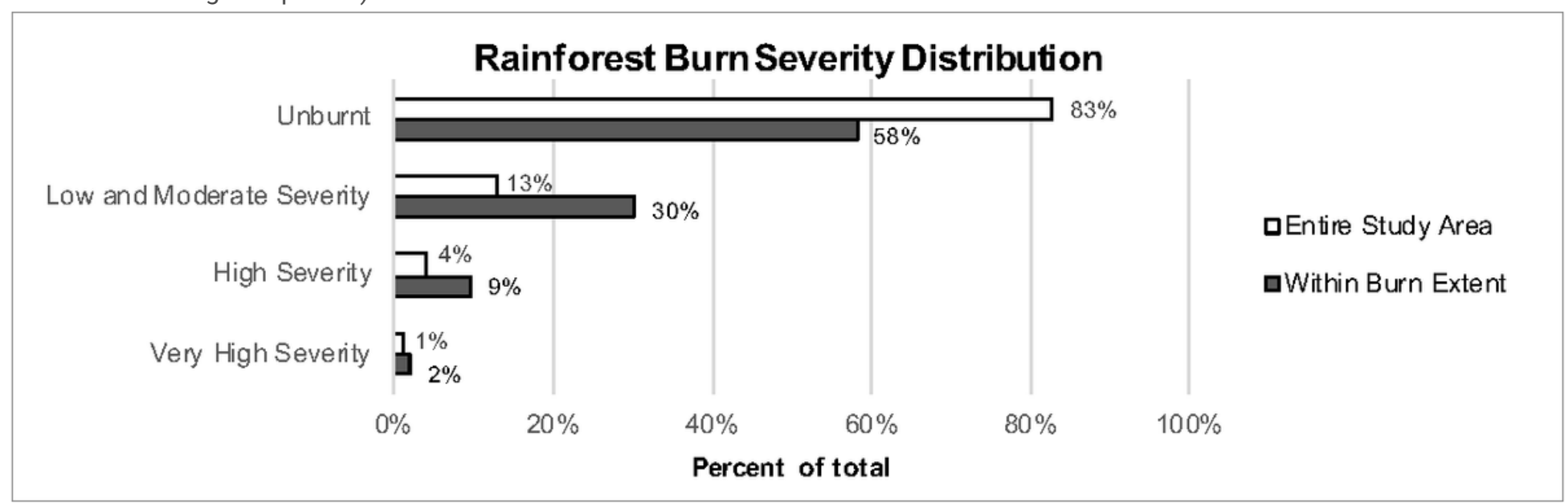

\section{Figure 3}

Percentage of rainforest points burnt for the Eastern Australian Temperate and Subtropical Forests Conservation Manage-ment Zone study area (white) and within the GEEBAM burn extent and $1 \mathrm{~km}$ buffer (dark grey). Burn extent was calculated for the period of 1 July 2019 to 24th of February 2020 (DAWE 2018; DAWE 2020). 


\section{Burn Severity and Topographic Variables}

A
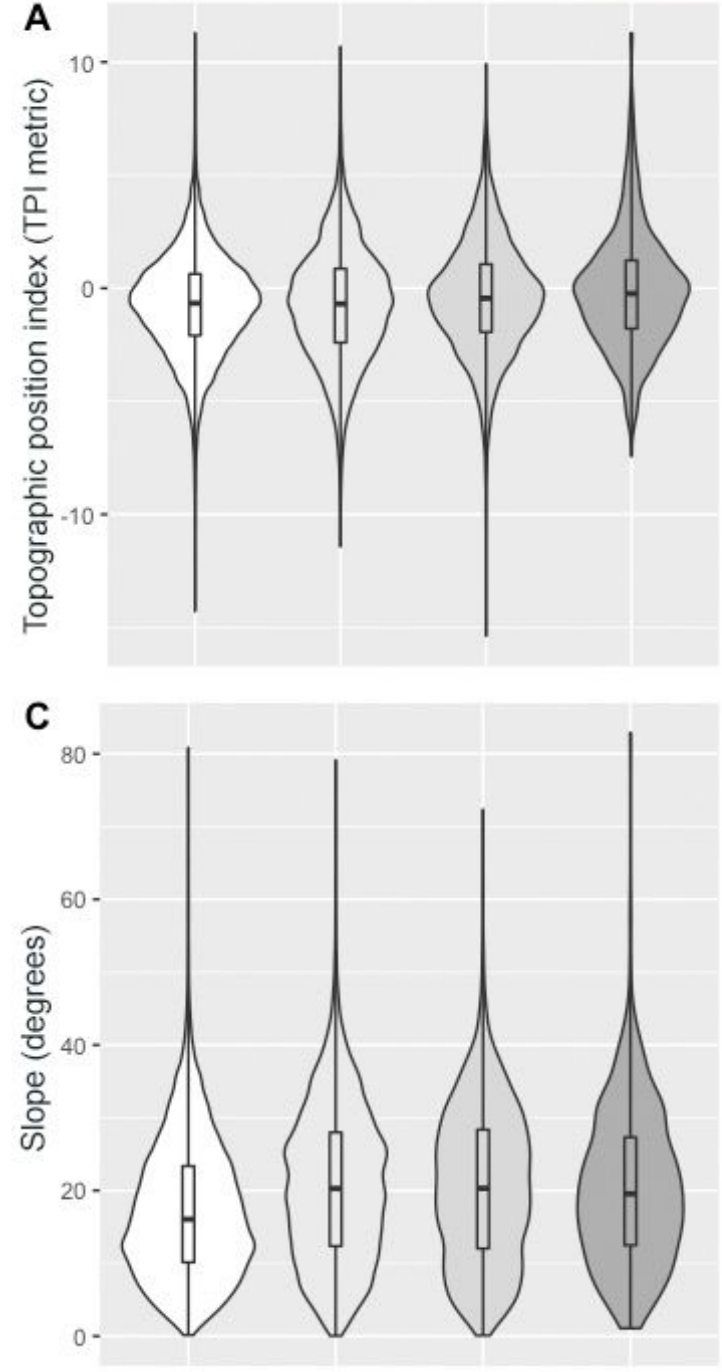

B

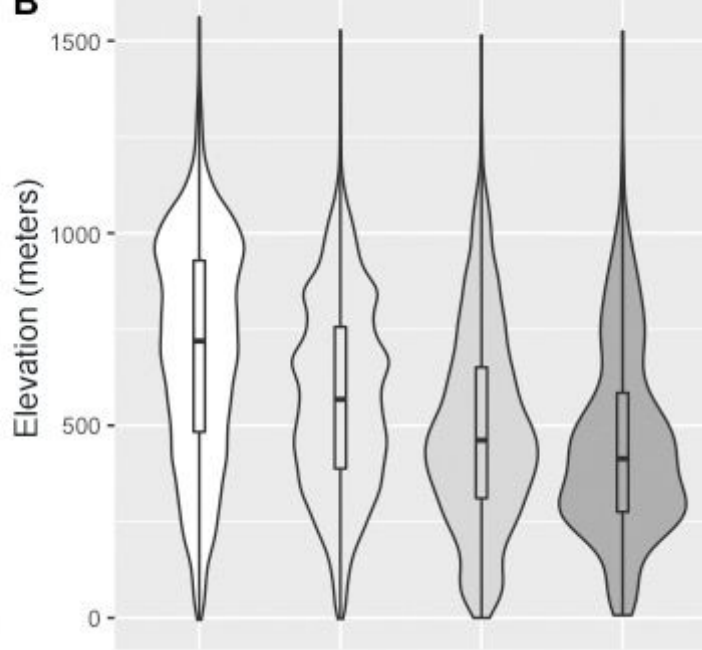

Burn Severity

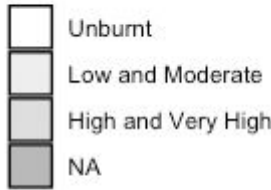

\section{Figure 4}

Violin Plots with overlaid boxplots representing GEEBAM burn severity of rainforests within burn extent and $1 \mathrm{~km}$ buffer zone in comparison with key topographic variables $(n=42,502)$. (A) Topographic position index, where positive values represent with ridges and negative values represent valleys (TPI scale varies depending upon the study resolution). (B) Ele-vation in meters in comparison with burn severity. (C) Slope in degrees. 


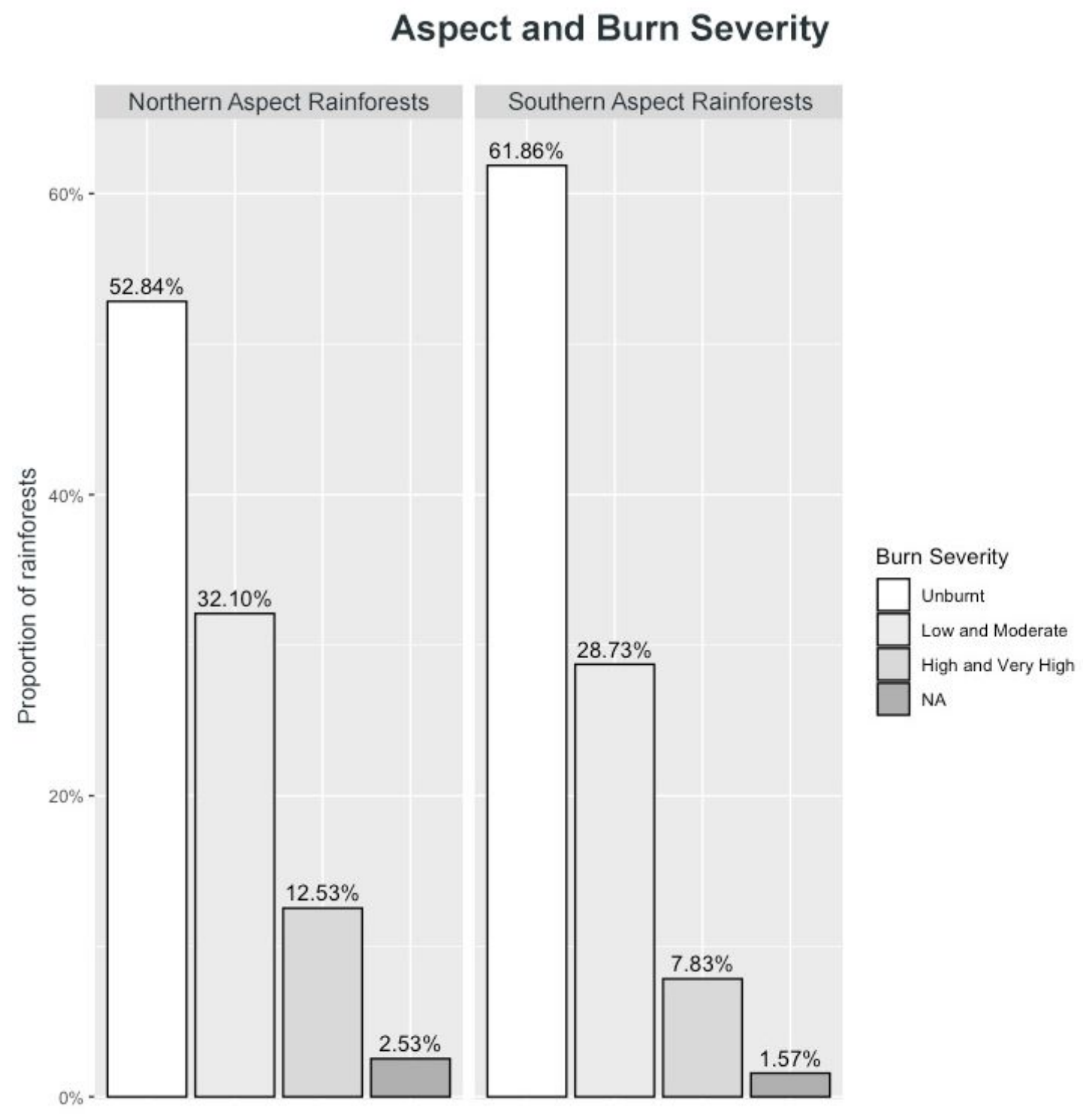

Figure 5

North facing aspects (0-90 degrees/270-360 degrees; non-poleward facing) and south facing aspects (90 - 270 degrees; poleward facing) in comparison with burn extent per burn severity category. Cool temperate rainforest and dry rainforest or vine thickets were excluded in this analysis due to their lower sample size.

\section{Supplementary Files}

This is a list of supplementary files associated with this preprint. Click to download.

- DescriptiveStatisticsAdditionalFigures.docx

- RainforestBurnSeverityMap.jpg 